\title{
The Use of Progressive Technologies in Logistics of Slovak Automotive Enterprises
}

\author{
Patrik Richnák ${ }^{1, *}$ \\ ${ }^{1}$ University of Economics in Bratislava, Faculty of Business Management, Department of Production \\ Management and Logistics, Dolnozemská cesta 1, 85235 Bratislava, Slovak Republic
}

\begin{abstract}
.
Research background: Rapid technical progress supports the development of advanced technologies, which increases the requirements of customers who emphasize the quality of products. We can expect revolutionary changes in every business area, but especially in production and logistics, as they will be most subject to the implementation of artificial intelligence, robotics, augmented reality, 3D printing and other technologies related to Industry 4.0 as a representative of The Fourth Industrial Revolution. Based on these facts, every enterprise is looking for new ways to reduce costs not only in production but also logistics, speed up and simplify the production and logistics process. One of the effective ways to achieve this is to use and implement progressive technologies in logistics. The aim of the paper was to examine progressive technologies in logistics that are used in Slovak automotive enterprises and then analyse selected technologies. The paper is divided into two parts. The first part of the paper is devoted to a literary view of progressive technologies in logistics. The second part provides an insight into a comparative analysis of selected technologies in logistics of 65 Slovak automotive enterprises. The paper used several research methods, which include: literature search, system analysis, comparative analysis, induction, deduction and visualization method. Progressive technologies in today's conditions are a prerequisite for effective results in every enterprise in the form of economy and efficiency. The use and continuous improvement of progressive technologies in automotive enterprises must be one of the necessary activities in the management of the enterprise in order to maintain competitiveness in the market.
\end{abstract}

Purpose of the article: The aim of the paper was to examine progressive technologies in logistics that are used in Slovak automotive enterprises and then analyse selected technologies. The paper is divided into two parts. The first part of the paper is devoted to a literary view of progressive technologies in logistics. The second part provides an insight into a comparative analysis of selected technologies in logistics of 65 Slovak automobile enterprises.

Methods: The paper used several research methods, which include: literature search, system analysis, comparative analysis, induction, deduction and visualization method.

\footnotetext{
*Corresponding author: patrik.richnak@euba.sk
} 
Findings \& Value added: Progressive technologies in today's conditions are a prerequisite for effective results in every enterprise in the form of economy and efficiency. The use and continuous improvement of advanced technologies in automotive enterprises must be one of the necessary activities in the management of the enterprise in order to maintain competitiveness in the market.

Keywords: progressive technologies, technologies in logistics, business logistics, supply chain management, automotive industry

JEL Classification: $L$ 90; $M 11 ; O 14$

\section{Introduction and literature review}

Business entities are in the conditions of globalization and free movement within the market decide in which state it would be appropriate to implement business activity [1]. The economies of individual countries, as well as the world economy as a whole, have to face constant change and a rapidly changing environment. Under the influence of globalization and internationalization, multinational corporations are emerging and competition is taking on an international dimension. For enterprises operating in highly turbulent and uncertain conditions, it is becoming necessary to adapt their traditional ways of doing business to the changed situation and new market opportunities [2].

Current approaches in logistics are focused on sustainable development of enterprises and society [3]. On account of that businesses will need to react to meet these new challenges in order to be successful. In our fast-moving world, the winners will be companies that can sense change and respond accordingly [4].

The increasing pace of digitization, integration of new ICT in the context of Industry 4.0 increases the demands on the skills and knowledge not only of company employees, but also managers [5]. We are currently witnessing that the ongoing new industrial revolution is bringing changes and the development of progressive logistics technologies. Their use in logistics is a prerequisite for effective results in the form of economy and efficiency. Their use and continuous improvement must be a necessary activity in the management of the enterprise. In this paper, we characterize selected progressive technologies based on literature search - Radio Frequency Identification, Quick Response and Pick-by-Systems.

Technology of Radio Frequency Identification (RFID) represents technology, which automatically identifies and collects data with the aid of radio waves. The most important and characteristic sign is that it allows to connect unique identification. Another information read by wireless device via microchip, which is placed by transportation units, products etc. RFID in connection with databases and communication webs provides effective way to provide new services and applications in different environments. Application of RFID leads towards achievement of high level process automation with high level of accuracy in operations, which also increases effectiveness [6].

Radio frequency identification (RFID), which is a key technology to enable Internet of Things (IoT), can identify objects automatically by employing wireless communication. Typically, an RFID system includes tags, a reader and back-end systems [7].

Transponder, also called data carrier - chip - RFID tag - label - identification represents the part of the whole system; reading device, which might be named reader or RFID scanner and software equipment Middleware. Transponder (data carrier, chip, RFID tag) is usually plastic resistant label which includes chip. Every transponder consists of chip, antenna, base material and also unique identification and it might include other parts such as environmental sensors, ciphering component etc. [8]. 
The use of RFID will enable organizations to collect, analyze and use data better. RFID tags are designed to replace bar codes, primarily because more data can be placed on a RFID tag than on a bar code. This added data capacity will make it possible for users to compile more information about product history and traceability, customer preferences, demand patterns, and other relevant facts. Advocates believe RFID will improve customer service by better matching supply with demand. It should also reduce costs through improved inventory management and avoidance of obsolescence and waste [9].

Radio frequency identification (RFID) has been widely used in supporting the logistics management on manufacturing shopfloors where production resources attached with RFID facilities are converted into smart manufacturing objects (SMOs) which are able to sense, interact, and reason to create a ubiquitous environment [10].

In RFID-based systems for smart applications, an RFID-tag may be operated from several meters distance and it does not require to be put within direct line-of-sight of the reader like a barcode system does. Therefore, the traditional barcode system will be replaced by the RFID authentication system in near future since in the later technology reading of a large amount of data within short span is possible [11].

QRC has been an established technology for the last 20 years and utilised worldwide across industries with mixed success in marketing applications. However, the promise of QRC technology amidst the rise of mobile marketing has been met with general consumer ambivalence as other options are emerging for companies as well as consumers to utilise. New alternatives to QRC, including near field communication (NFC) and augmented reality (AR), are being incorporated into corporate digital strategies [12].

QR codes are two-dimensional matrix barcodes. Last decade witnessed a steady growth in commercial and business oriented usage of these QR codes with the advent of smart and web capable mobile phones [13].

These, two-dimensional graphic images of high-density are basicallyjust barcodes comprised of digital squares instead of bars. The composite ofthese "squares," often looking like crossword puzzles or steroids, come togetherto create codes, which, in turn, house the data that are scanned by mobile devices. The devices quickly scan and digest the code's information block, translating itinto hyperlinks or text information [14].

QR code is the technology that deliver information to the users in the form of code. QR code is a 2D matrix barcode image that scan using smartphone camera with QR reader application. QR code can be read through mobile device which has the QR code reader facilities. Information is encoded into a $Q R$ code by $Q R$ Code generator. Data easily encoded in to QR codes by using any freely available QR code generators [15].

The quick response (QR) supply chain system has received a great deal of attention in the recent past because of the advances in many new technologies such as RFID systems and mobile computing. Establishment of supply chain practices, such as collaborative planning, forecasting, and replenishment (CPFR), and vendor managed inventory (VMI) has also contributed to the development of QR in industrial practice [16].

Warehouse System Management works with storage positions, one-level and multilevel packaging which enables to monitor individual storage movements. In application of system management there are combined also other technologies assisting to decrease error rates and save time. There we include for example RFID, Pick by Voice, Pick by Light, conveyors and others. The sensor-based method uses a RFID tag [17], a laser pointer, a wireless sensors [18] and a laser sensor [19] [20], for pallet detection and location

$\mathrm{PbV}$ is a technology that makes use of audio and voice control to guide the picking process. The picker wears a headset that is connected to a small terminal that can be attached to his or her belt. This terminal communicates wirelessly with the WMS [21].

Bächler et al. [22] says that when pick by light of guided picking the picker receives all the necessary picking information from small display boards, which are mounted above or 
below the shelving bay. The lighting of a lamp indicates the correct removal shelf, a display shows the quantity of parts to be taken and a button must be pressed to confirm a removal. Advantages are the high transparency of inventory changes, the online collection of job statuses and the possibility of parallel order processing.

More worldwide companies are using voice systems to automate customer service, order placements, banking transactions and information dissemination. As this technology has a continuation in its growth, the companies are becoming increasingly aware of the benefits considering and accepting voice technology as potential for process optimization [23].

\section{Methodology}

The aim of the paper was to examine progressive technologies in logistics that are used in Slovak automotive enterprises and then analyse selected technologies. The paper is divided into two parts. The first part of the paper is devoted to a literary view of progressive technologies in logistics. The second part provides an insight into a comparative analysis of selected technologies in logistics of 65 Slovak automobile enterprises.

The sources of initial knowledge in the processing of definitions were professional foreign and domestic literature dealing with the researched issues. In the theoretical part of the paper, we used a literature search and created a comprehensive theoretical text from the acquired knowledge and information. With the help of comparative analysis, we looked the same and different features views of various authors who deal with relevant field. The system analysis served us to define the research problem and subsequently to focus on research and determine the solution of the problem. Using induction and deduction, we drew general conclusions from the information and knowledge obtained. In the paper also used the visualization method in the form of clear figures. The object of the research was a sample of 65 Slovak automobile enterprises operating in Slovakia. The questionnaire survey was carried out by inquiry method using a standardized questionnaire.

\section{Results and discussion - Research in the Slovak automotive enterprises}

In the following part of the paper, the results of the research in 65 Slovak automotive enterprises were interpreted and evaluated. The results of the research concerned the use of selected progressive technologies in logistics - Radio Frequency Identification, Quick Response and Pick-by-Systems. The use of selected progressive technologies in small, medium-sized and large automotive enterprises in Slovakia was also evaluated. Radio Frequency Identification, Quick Response and Pick-by-Systems were also interpreted from the point of view of use in business logistics and the field used by regions in Slovakia.

Based on Figure 1, we can see the percentage shares of the use/non-use of progressive technologies in logistics of Slovak automotive enterprises. The largest percentage $(98 \%)$ of use was achieved by Radio Frequency Identification. Quick Response obtained also high percentage $(73 \%)$ of use in Slovak automotive enterprises. Pick-by-Systems is used by automotive enterprises with a share of $49.3 \%$. Pick-by-Systems obtained the largest percentage $(51 \%)$ of non-use of progressive technologies in logistics. Slovak automotive enterprises do not use Quick Response with a share of $27.2 \%$. The smallest percentage $(2.5 \%)$ of non-use of progressive technologies was obtained by Radio Frequency Identification. 


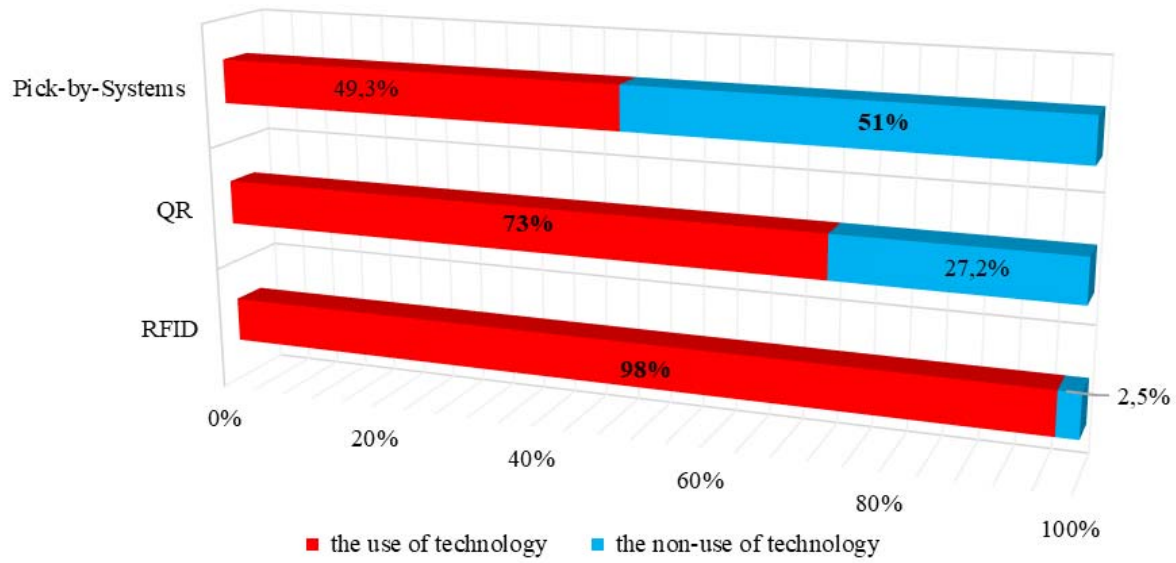

Fig. 1. The use/non-use of progressive technologies in logistics of enterprises. Source: own research

Figure 2 shows the use of progressive technologies of Slovak automotive enterprises according to business size. The use of Pick-by-Systems reached the largest percentage (68.6\%) in large enterprises. Quick Response is used by large automotive enterprises in Slovakia with a share of $47.6 \%$. Radio Frequency Identification is used by large enterprises with a share of $43.2 \%$. In medium-sized enterprises, the percentages are balanced. The highest percentage (41\%) was achieved by Quick Response. Medium-sized automotive enterprises in Slovakia use Radio Frequency Identification with a share of 38\%. Pick-bySystems is used by respondents with a share of 30\%. In small automotive enterprises, there are significant differences in the use of advanced technologies in logistics. The largest percentage (18.8\%) was achieved by Radio Frequency Identification. Quick Response achieved a share of $11.5 \%$. The smallest percentage $(1.4 \%)$ was obtained by Pick-bySystems. This progressive technology is used to a minimum by small automotive enterprises in Slovakia.

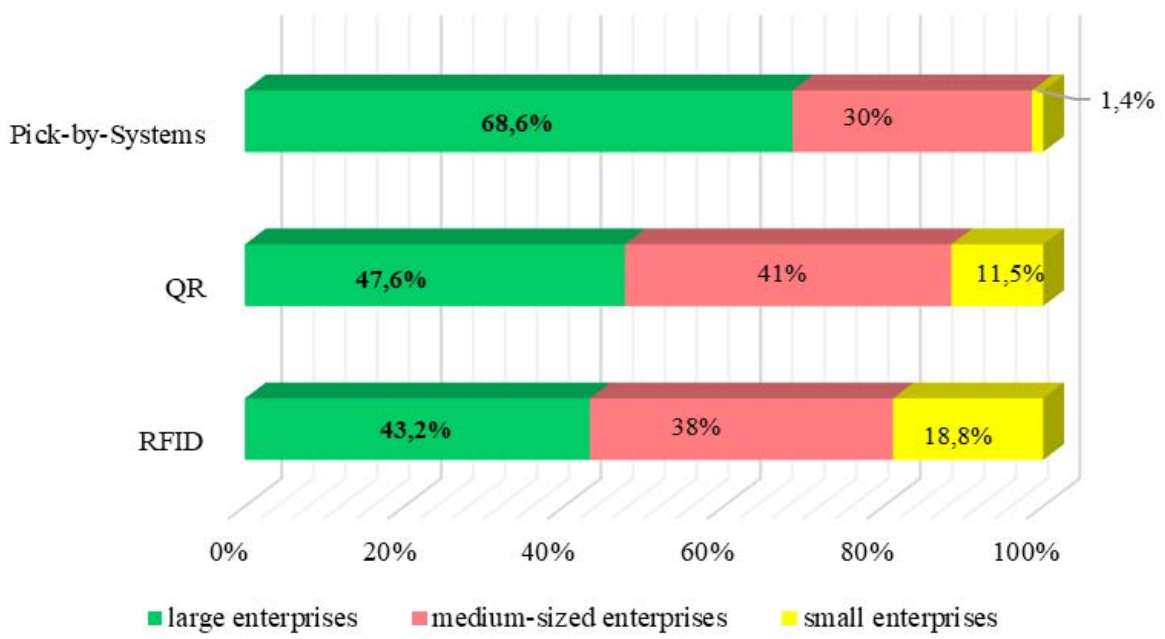

Fig. 2. The use of progressive technologies according to business size. Source: own research

Figure 3 reveals, the use of progressive technologies in logistics according to business logistics fields. The use of progressive technologies in procurement logistics is very 
different. In procurement logistics, Slovak automotive enterprises with the largest percentage (20.3\%) use Quick Response. Radio Frequency Identification is used by respondents in procurement logistics with a share of $6.8 \%$. It is least used in procurement logistics Pick-by-Systems. This progressive technology achieved only $0.8 \%$. In production logistics, Slovak automotive enterprises with the largest share $(47.2 \%)$ use Radio Frequency Identification. Quick Response is used by automotive enteprises in production logistics with a share of $38.6 \%$. Pick-by-Systems achieved a utilization rate of $24.5 \%$. In distribution logistics of Slovak automotive enteprises, high percentages of the use of progressive technologies were achieved. There are high percentages of the use of progressive technologies in the distribution logistics of Slovak automotive companies. Pick-by-Systems have the largest percentage (74.7\%). Radio Frequency Identification is used in distribution logistics of automotive enteprises with a share of $46 \%$. Quick Response is used by respondents with a share of $41.1 \%$.

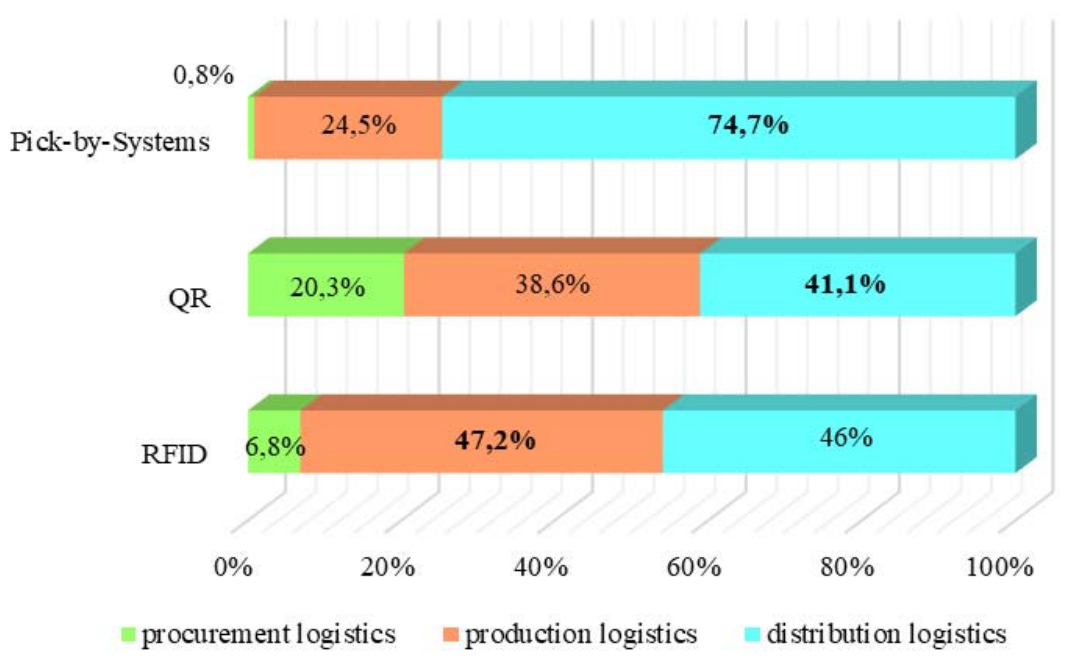

Fig. 3. The use of progressive technologies according business logistics fields. Source: own research

Figure 4 shows the use of Radio Frequency Identification, Quick Response and Pick-bySystems in automotive enterprises by regions in Slovakia. The radar graph was created based on the mean values. Radio Frequency Identification is mostly used in enterprises in Trnava Region. The mean value achieved 3.3. Žilina Region (3.2), Bratislava Region (3.1) and Banská Bystrica Region (3) recorded balanced mean values. The lowest mean value (2.4) of Radio Frequency Identification was recorded in Košice Region. Quick Response is the most used in automotive enterprises in Žilina Region. The mean value achieved 3.4. Automotive enterprises in Trnava and Bratislava Regions obtained a higher mean values $(3.2 ; 3,1)$ in the use Quick Response. The lowest mean value (2.3) of Quick Response was recorded in enterprises of Prešov Region. Pick-by-Systems are the most used in enterprises in Bratislava Region. The mean value achieved 2.1. The lowest mean value $(0.5)$ of Pickby-Systems was recorded in enterprises of Košice Region. 


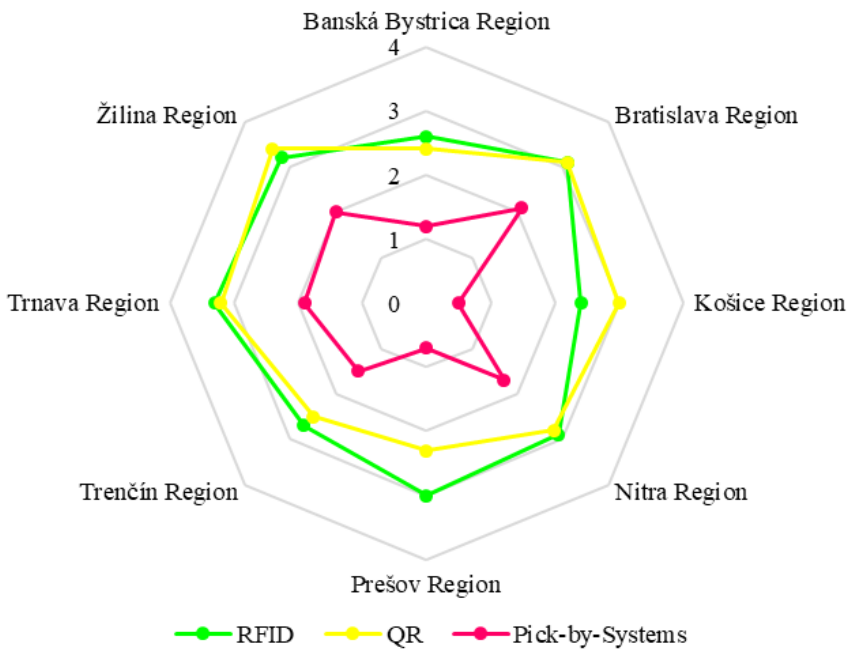

Fig. 4. The use of progressive technologies by regions of Slovakia. Source: own research

\section{Conclusions}

In the current turbulent business environment and progressive globalization, the importance of flexible adaptation of economic organizations to change is growing [24]. Today, if companies want to stay at the forefront of the market and meet the needs and desires of their customers, they need to be flexible, that is, to be able to adapt their business processes to demand. If the company is not flexible enough and adaptable to customer demand, there may be a situation where consumers start to turn to competing companies that will be able to satisfy their wishes and needs [25].

The aim of the paper was to examine progressive technologies in logistics that are used in Slovak automotive enterprises and then analyse selected technologies. The paper is divided into two parts. The first part of the paper is devoted to a literary view of progressive technologies in logistics. The second part provides an insight into a comparative analysis of selected technologies in logistics of 65 Slovak automobile enterprises.

In the researched Slovak automotive companies, we focused on selected progressive technologies. Respondents use Radio Frequency Identification the most with a share of 98\%. Most respondents (51\%) do not use Pick-by-Systems. In large automotive enterprises in Slovakia they use mainly Pick-by-Systems (68.6\%). Quick Response (41\%) is the most used in medium-sized enterprises. Small enterprises are dominated by the use of Radio Frequency Identification (18.8\%). Progressive technology in logistics - Pick-by-Systems is used by enterprises mainly in distribution logistics. The enterprises usage most of Radio Frequency Identification in production logistics. Radio Frequency Identification is mostly used in enterprises in Trnava Region. Quick Response is the most used in automotive enterprises in Žilina Region. Pick-by-Systems are the most used in enterprises in Bratislava Region. 
The paper is a partial output within VEGA No. 1/0375/20 research project titled „New Dimension in the Development of Production Management and Logistics under the Influence of Industry 4.0 in Enterprises in Slovakia“.

\section{References}

1. Vavrova, K. (2015). Tax incentives of business entities in selected countries of the EU in the context of globalization. In: Kliestik, T. (Eds.), Globalization and its socioeconomic consequences (pp. 855-863). Rajecke Teplice: Proceedings Paper.

2. Szabo, L., Cambalikova, A. (2017). Moderné trendy v manažmente a ich uplatňovanie v podnikoch na Slovensku, Brno: Tribun EU.

3. Mala, D., Sedliacikova, M., Kascakova, A., Bencikova, D., Vavrova, K., Bikar, M. (2017). Green logistic in Slovak small and medium wood-processing enterprises. Bioresources, 12(3), 5155-5173.

4. Cambalikova, A., Szabo, L. (2017). Modern trends in management and their application in controlling. In Socio-economic perspectives in the age of XXI century globalization (pp. 475-488). Tirana : Proceedings Paper.

5. Bolek, V., Kokles, M., Romanova, A., Zelina, M. (2018). Information Literacy of Managers: Models and Factors. Journal of Business Economics and Management, 19(5), 722-741.

6. Ahson, S., Ilyas, M. (2008). RFID Handbook: Applications, Technology, Security, and Privacy. Boca Raton: CRC Press.

7. Su, J., et al. (2019). Energy Efficient Tag Identification Algorithms For RFID: Survey, Motivation And New Design. IEEE Wireless Communications, 26(3), 118-124.

8. Reaz, M. B. I. (2013). Radio frequency identification from system to applications. Rijeka: InTech.

9. Crandall, R. E, Crandall, W. (2015). How Management Programs Can Improve Performance: Selecting and Implementing the Best Program for Your Organization. Charlotte, North Carolina : Information Age Publishing, Inc.

10. Zhong, R. Y., Huang, G.Q., Lan, S.L., Dai, Q.Y., Xu, C., Zhang, T. (2015). A Big Data Approach for Logistics Trajectory Discovery from RFID-Enabled Production Data. International Journal of Production Economics, 165, 260-272.

11. Gope, P., Amin, R., Islam, S.K.H., Kumar, N., Bhalla, V.K. (2018). Lightweight and Privacy-Preserving RFID Authentication Scheme for Distributed IoT Infrastructure with Secure Localization Services for Smart City Environment. Future Generation Computer Systems, 83, 629-637.

12. Brooks, J. R., et al. (2019). Revisiting Quick Response (QR) Code Technology: Corporate Perspectives. International Journal of Mobile Communications, 17(1).

13. Shettar, I. M. (2016). Quick Response (QR) Codes in Libraries: Case study on the use of QR codes in the Central Library, NITK. In Proc. TIFR-BOSLA National Conference on Future Librarianship. 129-134.

14. Bashir, I., Naik, K., Madhavaiah, C. (2013). Potential Business Applications of Quick Response (QR) Codes. Prajnan, XLI(4).

15. Wani, S. (2019). Quick Response Code: A New Trend in Digital Library. International Journal of Library and Information Studies, 9(1).

16. Choi, T.M., Sethi, S. (2010). Innovative Quick Response Programs: A Review. International Journal of Production Economics, 127(1), 1-12. 
17. Jeon, S. et al. (2010). Localization of pallets based on passive RFID tags. In International Conference on Information Technology. 834-839.

18. Shen, J., Tan, H.W., Wang, J., Wang, J.W., Lee, S. (2015). A novel routing protocol providing good transmission reliability in underwater sensor networks. Journal of Internet Technology, 16(1), 171-178.

19. He, Z. et al. (2010). Feature-to-feature based laser scan matching for pallet recognition. In International Conference on Measuring Technology and Mechatronics Automation: 2010, 260-263.

20. Lecking, D., Wulf, O., Wagner, B. (2006). Variable pallet pick-up for automatic guided vehicles in industrial environments. In IEEE Conference on Emerging Technologies and Factory Automation: 2006 (pp. 1169-1174). Prague: IEEE International Conference on Emerging Technologies and Factory Automation-ETFA.

21. de Vries, J., de Koster, R., Stam, D. (2015). Exploring the Role of Picker Personality in Predicting Picking Performance with Pick by Voice, Pick to Light and RF-Terminal Picking. International Journal of Production Research, 54(8), 2260-2274.

22. Bächler, A., Bächler, L., Autenrieth, S., Kurtz, P., Hörz, T., Heidenreich, T., Krüll, G. (2016). A Comparative Study of an Assistance System for Manual Order Picking -Called Pick-by-Projection -- with the Guiding Systems Pick-by-Paper, Pick-by-Light and Pick-by-Display. In Bui, T.X., Sprague, R.H. (Eds.), 49th Hawaii International Conference on System Sciences (HICSS) (pp. 523-531). Koloa: Proceedings of the Annual Hawaii International Conference on System Sciences.

23. Dujmesic, N., Bajor, I., Rozic, T., (2018). Warehouse Processes Improvement by Pick by Voice Technology. Tehnicki Vjesnik - Technical Gazette, 25(4).

24. Cambalikova, A. (2018). Moderné manažérske metódy uplatňované v kontrole. In Trendy interného kontrolovania $v$ podnikatel'ských subjektoch vo svetle nových výziev: [recenzovaný zborník vedeckých statí] (pp. 88-96). Ceske Budejovice : Proceedings Paper.

25. Porubanova, K., Puckova, N. (2019). Optimalizácia podnikových procesov využitím analýzy hodnotových tokov. Ekonomika, financie a manažment podniku XIII: zbornik vedeckých statí pri príležitosti Týždn̆a vedy a techniky (pp. 431-440). Bratislava: Ekonom. 